\section{Brazilian Journal \\ of Chemical \\ Engineering}

ISSN 0104-6632

Printed in Brazil

www.scielo.br/bjce

Vol. 34, No. 04, pp. 971 - 983, October - December, 2017

$($ (c) $)$ EY

dx.doi.org/10.1590/0104-6632.20170344s20160297

\title{
DAIRY MANURE WASTEWATER IN SERIAL UASB REACTORS FOR ENERGY RECOVERY AND POTENTIAL EFFLUENT REUSE
}

\author{
A. C. V. Montoya ${ }^{1}$, R. C. da S. Mazareli ${ }^{1}$ \\ D. C. da Silva ${ }^{1}$, R. A. de Oliveira ${ }^{1 *}$, V. D. Leite ${ }^{2}$ \\ ${ }^{1}$ Universidade Estadual Paulista “Julio de Mesquita Filho" (UNESP), Environmental Sanitation Laboratory, Department of Agricultural \\ Engineering, Paulo Donato Castellane, s.n, 14884-900, Jaboticabal - SP, Brazil. Phone: (+55) (16) 3209 7289, Fax: (+55) (16) 3203 3341 \\ *E-mail: raoder@fcav.unesp.br \\ ${ }^{2}$ Universidade Estadual da Paraíba, Science and Technology Center, Chemistry Department, 10 Floriano Peixoto Bodocongo, 58100-000 \\ Campina Grande - PB, Brazil. Phone: (+55) (83) 33315 3352, Fax: (+55) (83) 33153333.
}

(Submitted: January 29, 2016; Revised: August 26, 2016; Accepted: September 2, 2016)

\begin{abstract}
This manuscript addresses the use of dairy manure wastewater (DMW) as a substrate for methane production in a high rate system - two serial UASB reactors - and the characterization of the effluent in the different phases of the treatment. Two experimental conditions were applied. In the first, the organic load rate (OLR) was 6.2 gCOD $_{\text {tot }}$ $\mathrm{L}^{-1} \mathrm{~d}^{-1}$ and the hydraulic retention time (HRT) was 12 days, whereas in experiment 2 they were $14.2 \mathrm{gCOD}_{\text {total }} \mathrm{L}^{-1}$ $\mathrm{d}^{-1}$ and 7.5 days, respectively. The reactors showed a high capacity of removal of COD and solids, i.e., above $71 \%$, which led to bioenergy productivities of 0.55 and $0.73 \mathrm{~L} \mathrm{CH}_{4} \mathrm{~L}^{-1} \mathrm{~d}^{-1}$ in experiments 1 and 2, respectively. The methane yield in UASB1 was 0.19 and $0.08 \mathrm{~L} \mathrm{CH}_{4} \mathrm{~g} \mathrm{COD}_{\text {rem }}{ }^{1}$, respectively, in experiments 1 and 2. The methane yield in UASB1 was greater than UASB2, with approximately $70 \%$ of methane content in the biogas in this reactor.The effluent characterization showed micro and macronutrients - some in high concentrations, as nitrogen, phosphorous, $\mathrm{K}$, and $\mathrm{Fe}$ between 12.1 and $521.4 \mathrm{mg} \mathrm{L}^{-1}$, and others in low concentrations, as $\mathrm{Ca}, \mathrm{Mg}, \mathrm{Zn}$ and $\mathrm{Mn}$ between 0.6 and $13 \mathrm{mg} \mathrm{L}^{-1}$. $\mathrm{Na}$ was not removed from the UASB systems and its concentration in the effluent was raised to $23.5 \%$ in comparison with the substrate.
\end{abstract}

Keywords: Livestock waste, Bio-energy, High-rate reactors, Nutrients.

\section{INTRODUCTION}

Milk is one of the most consumed foods worldwide, due to its variety of important nutrients for metabolism and physiologically functional compounds, such as bioactive peptides, antioxidants, and omega-3 (Yao et al., 2016). Because of the increase in its demand, animal confinement systems have been an alternative for productivity enhancement and reductions in management costs (Silva and Roston, 2010). However, the disadvantage of such systems is that they generate a high amount of polluting waste (Puget et al., 2004) - on average, $37 \mathrm{~kg} \mathrm{cow}^{-1} \mathrm{~d}^{-1}$ in manure and urine forms (Tabatabaei et al., 2010). As a result, the effluent generation is 4.7 higher than the milk production (Silva and Roston, 2010).

Due to increased demands and rising prices for fossil fuels, livestock waste has been converted into renewable energy as a sustainable alternative. The biogas production is one of the several tools that can alleviate the problems of global warming, energy security and livestock waste generation. According to Appels et al. (2011), anaerobic digestion is an efficient alternative technology for the

\footnotetext{
* To whom correspondence should be addressed
} 
treatment of wastewater and sludge stabilization and offers advantages, such as production of biogas, agricultural recycling of organic matter and recovery of nutrients that remain in the effluents of anaerobic reactors.

Such agroindustrial wastes are characterized by the presence of salts, toxic elements, pathogens, high concentrations of nutrients and COD (Adhikari et al., 2015; Witarsa and Lansing, 2015), which make the DMW an adequate substrate for biogas production (mainly methane, $\mathrm{CH}_{4}$ ) and stable sludge (Witarsa and Lansing, 2015).

Arikan et al. (2015) obtained methane production values of $5.0 \mathrm{~m}^{3}$ week ${ }^{-1}, 0.37 \mathrm{~m}^{3} \mathrm{~kg}^{-1} \mathrm{SV}$ methane yield and a $44 \%$ reduction in volatile solids (VS). The authors operated a field-scale anaerobic digester at $35^{\circ} \mathrm{C}$ fed with scraped cow manure of $1.4 \mathrm{~kg} \mathrm{VS} \mathrm{m}^{3} \mathrm{~d}^{-1} \mathrm{OLR}$. They also reported a higher methane production of $8.6 \mathrm{~m}^{3}$ week ${ }^{-1}$ and $65 \% \mathrm{VS}$ removal, and OLR increase to $2.6 \mathrm{~kg} \mathrm{VS} \mathrm{m}^{3} \mathrm{~d}^{-1}$. Similarly, Rico et al. (2011a), reached a methane production of $10.3 \mathrm{~L}$ $\mathrm{CH}_{4} \mathrm{~L}^{-1} \mathrm{~d}^{-1}$ in a UASB reactor operating at $35^{\circ} \mathrm{C}$ and OLR of $40.8 \mathrm{~g} \mathrm{COD} \mathrm{L}^{-1} \mathrm{~d}^{-1}$, whose liquid fraction was separated by flocculation and screening.

In general, conventional systems such as digesters have been applied for the treatment of DMW in rural areas and exhibit high HRT, low nutrient removal and low methane production (Nikolaeva et al., 2013; Ogejo and $\mathrm{Li}, 2010)$. For improvements in their performance, highrate anaerobic systems, such as UASB reactors (Upflow Anaerobic Sludge Blanket) are a suitable alternative for the treatment of effluents with high organic solids concentrations, such as DMW, since cattle confinement systems are characterized by a high manure generation in small areas (Liu and Haynes, 2011). Such a configuration can enable high OLR applications, and provide lower HRT, continuous operation and a higher biodegradation rate, due to the retention of biomass of high metabolic capacity (Powar et al., 2013).

Additionally, a serial UASB configuration is adequate for the treatment of such residues, because the second reactor removes the remaining organic matter from the first reactor, which increases the amount of methane produced and water quality in comparison with an individual system.

Due to the limitation of the DMW treatment in UASB reactors, few studies on the characteristics of the effluent have been developed, in comparison with those on bio-digester systems, mainly regarding microand macronutrients. The effluent characterization is important, due to the potential negative effects, such as water eutrophication and soil salinization caused when the effluent is not correctly disposed. However, the potential use of the effluent in soil fertilizing or irrigation must also be taken into consideration.

In consequence, the exploitation of DMW, the application of high-rate reactors with wastes of high organic solids concentration, and potential re-use of bioenergy and an effluent in the agricultural sector are interesting topics to be more deeply studied.

This article addresses the evaluation of the methane production capacity of a two serial UASB reactors that treat DMW and the characterization of effluents in relation to macro- and micronutrients and organic matter. The focus is on the effect of the increase in the OLR and reduction in the HRT over the reactor's performance.

\section{MATERIALS AND METHODS}

\section{Dairy manure wastewater}

The DMW influent used for feeding the reactors was simulated by a dairy manure dilution. The manure was collected weekly by a confinement system located in the dairy cattle sector at São Paulo State University, in Jaboticabal. It was diluted in proportions of 500 and $800 \mathrm{~g}$ for $1 \mathrm{~L}$ of water in experiments 1 and 2, respectively. The mixture was then sieved in a $0.2 \mathrm{~mm}$ mesh (Nikolaeva et al., 2013).

\section{Serial UASB reactors}

The experimental unit consisted of two serial UASB reactors of $20 \mathrm{~L}$ (UASB1) and $40 \mathrm{~L}$ (UASB2) volumes (Figure 1) with four sludge collection points distributed along their horizontal axes.

Inoculum. The reactors were inoculated with $30 \%$ granular sludge from a UASB reactor that treats swine wastewater. The total solids (TS) were 4077 and $19230 \mathrm{mg}$ $\mathrm{L}^{-1}$ and volatile solids (VS) were 2866 and $12157 \mathrm{mg} \mathrm{L}^{-1}$ for UASB1 and UASB2, respectively.

Operational conditions. The reactors were monitored for 90 days, from October to December/2013 (Table 1), and operated at ambient temperature (between 20 and $\left.30^{\circ} \mathrm{C}\right)$. The temperature data were collected daily at an agrometeorological station located at São Paulo State University, in Jaboticabal, close to the experimental laboratory.

Organic loading rate and hydraulic retention time. The OLR applied increased from 6.2 (experiment 1) to $14.2 \mathrm{~g} \mathrm{COD}_{\text {total }} \mathrm{L}^{-1} \mathrm{~d}^{-1}$ (experiment 2) and the HRT decreased from 12 (experiment 1) to 7.5 days (experiment 2) (Table 1).

\section{Sampling and analytical methods}

Influent and effluent. Composite samples of influents and effluents of the reactors were collected twice a week and physical and chemical tests evaluated their $\mathrm{pH}$, chemical oxygen demand (COD), total suspended solids (TSS), volatile suspended solids (VSS), Total Kjeldahl Nitrogen (TKN) and ammonia nitrogen (N-am.) according to a standard procedure (APHA, 2005). Total alkalinity (TA) and Volatile fatty acids (VFA) were determined by 


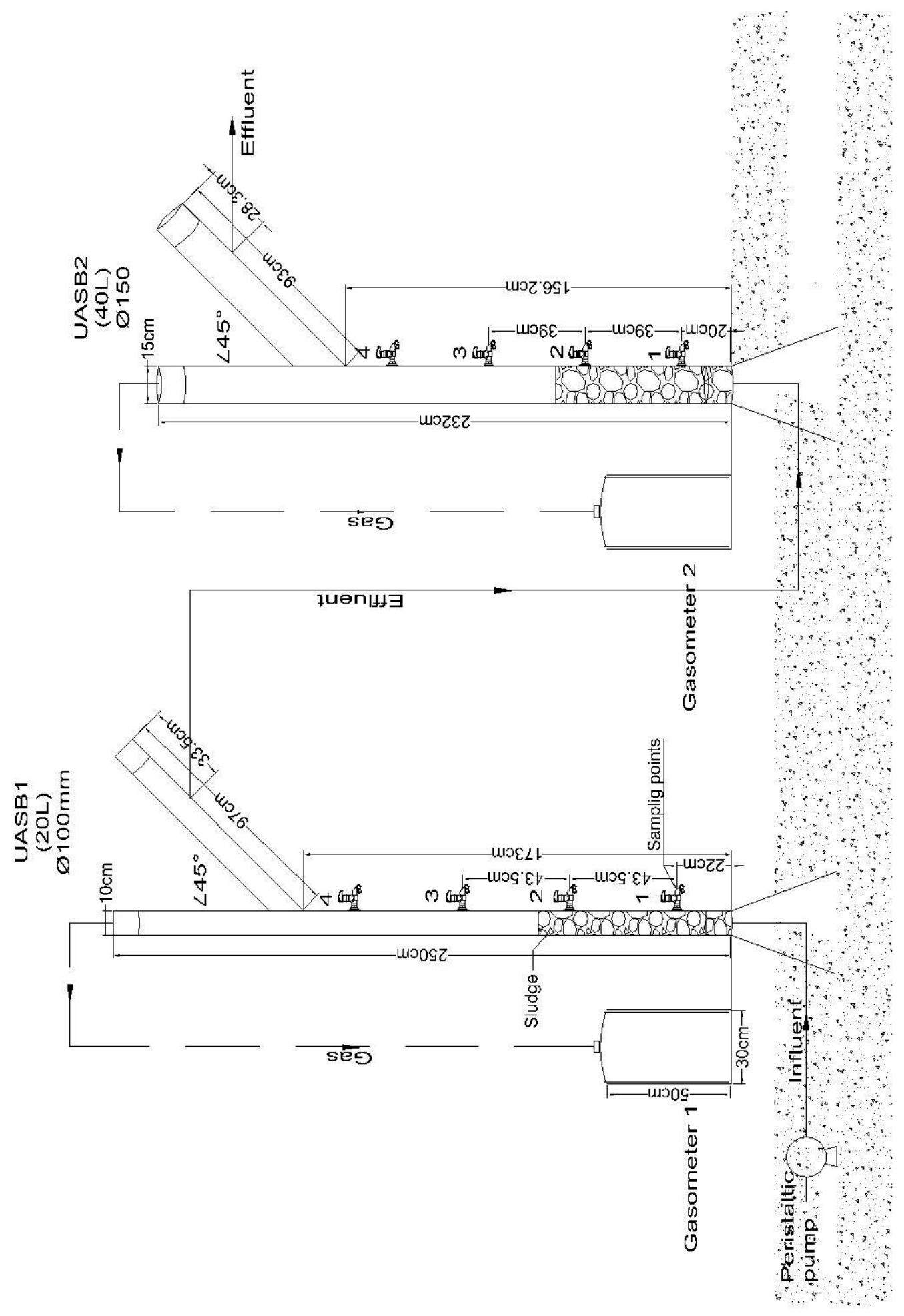


Jenkins et al. (1983) and Dilallo and Albertson (1961). Non-filtered samples of influent and effluent were digested by nitric perchloric acid and the total phosphorus (TP) was analyzed by the vanadomolybdophosphoric acid colorimetric method. Elements, such as sodium $(\mathrm{Na})$, potassium $(\mathrm{K})$, calcium $(\mathrm{Ca})$, magnesium $(\mathrm{Mg})$, iron $(\mathrm{Fe})$, manganese $(\mathrm{Mn})$, zinc $(\mathrm{Zn})$ and copper $(\mathrm{Cu})$ were quantified in the nitric perchloric acid digested by atomic absorption (APHA, 2005).TA and VFA were used for the calculationof bicarbonate alkalinity (BA) as $\mathrm{BA}=\mathrm{TA}-$ $(0,85)(0.83)$ (VFA) (McCarty, 1964).

Sludge. Sludge samples were collected monthly from different sludge sampling points (Figure 1). Total solids (TS) and volatile solids (VS) were determined according to a standard procedure (APHA, 2005).

Biogas. The biogas production was measured daily by fiberglass floating dome-type gasometers. The biogas composition was determined fortnightly by a gas chromatograph (FININGAN 6C-9001) equipped with a thermal conductivity detector, "Porapak Q" column (3 m 1/8 ") and a molecular sieve, according to the gas chromatographic method (APHA, 2005). The volume was corrected to Standard Temperature and Pressure conditions (STP, $273 \mathrm{~K}$ and $1 \mathrm{~atm}$ ) for the calculation of the methane production.

\section{Statistical Analysis}

The mean values and confidence limits $(95 \%)$ were calculated by Tukey test for multiple comparisons $(\alpha=0.5)$ and Statgraphics Centurium $X V$ version 15.1. Two treatments corresponding to two experiments with different replicates were evaluated according to the sampling frequency.

\section{RESULTS AND DISCUSSION}

\section{Methane production from dairy manure wastewater}

OLRs of 6.3 and $14.2 \mathrm{~g} \mathrm{COD}_{\text {total }} \mathrm{L}^{-1} \mathrm{~d}^{-1}$ in UASB1 were achieved through the feeding of the reactors with more concentrated substrates (Table 2).

The reduction in the organic matter concentration in UASB1 was $62-65 \%$. Therefore, the removal of the remaining organic matter content from the UASB1 effluent was enhanced in UASB2, which improved the potential for the methane conversion.

The performance of the two serial UASB reactors was evaluated according to $\mathrm{pH}, \mathrm{BA}$, and VFA (Table 2 ). Initially, the $\mathrm{pH}$ values of the influent were 6.8 and 6.4 for experiments 1 and 2, respectively, which are below the optimal range for the growth of methanogenic microorganisms. Nevertheless, the addition of a chemical alkalizer was not necessary, as the BA production in

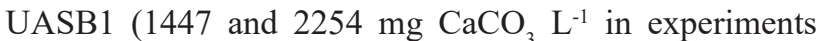
1 and 2, respectively) was enough for raising the $\mathrm{pH}$ to values higher than neutrality.

The minimal $\mathrm{pH}$ in both reactors was 7.0. According to Sakar et al. (2009), the $\mathrm{pH}$ required for methanogens ranges between 6.5 and 7.8 and 5.0 and 6.0 for the acidproducing bacteria. The $\mathrm{pH}$ observed in both UASB systems was adequate for methanogenic archaeas and avoided the separation of acidogenic and methanogenic phases in different reactors.

Influents with high VFA concentrations, i.e., 2297 and $3039 \mathrm{mg} \mathrm{L}^{-1}$, were obtained in experiments 1 and 2, respectively. During experiment 2, the OLR was superior

Table 1. Operational conditions of the two serial UASB reactors.

\begin{tabular}{lccccc}
\hline Experiment & $\begin{array}{c}\text { OLR } \\
\left(\mathbf{g ~ C O D ~ L}^{-1} \mathbf{d}^{-1}\right)\end{array}$ & $\begin{array}{c}\text { Duration } \\
(\mathbf{d})\end{array}$ & \multicolumn{2}{c}{$\begin{array}{c}\text { HRT } \\
(\mathbf{d})\end{array}$} & $\begin{array}{c}\text { Substrate concentration } \\
\left(\mathbf{m g ~ C O D ~ L}^{-1}\right)\end{array}$ \\
\hline 1 & 6.2 & 63 & 4.0 & 8.0 & 25117 \\
2 & 14.2 & 35 & 2.5 & 5.0 & 35548 \\
\hline
\end{tabular}

Table 2. VFA, BA and $\mathrm{pH}$ values and methane production of two serial UASB reactors.

\begin{tabular}{|c|c|c|c|c|c|c|c|c|c|c|c|}
\hline \multirow[b]{2}{*}{ Experiment } & \multirow[b]{2}{*}{$\begin{array}{c}\text { Temp. } \\
\left({ }^{\circ} \mathrm{C}\right)\end{array}$} & \multirow[b]{2}{*}{ Reactor } & \multirow{2}{*}{$\begin{array}{c}\text { OLR } \\
\left(\mathrm{g} \mathrm{CODL}^{-1}\right. \\
\left.\mathrm{d}^{-1}\right)\end{array}$} & \multirow[b]{2}{*}{$\begin{array}{l}\text { HRT } \\
\text { (d) }\end{array}$} & \multirow[b]{2}{*}{ pH } & \multirow{2}{*}{$\begin{array}{c}\text { VFA } \\
\left(\mathbf{m g ~ L}^{-1}\right)\end{array}$} & \multirow{2}{*}{$\begin{array}{c}\text { BA } \\
\left(\mathrm{mg} \mathrm{L}^{-1}\right)\end{array}$} & \multirow[b]{2}{*}{$\begin{array}{l}\mathrm{CH}_{4} \\
(\%)\end{array}$} & \multirow{2}{*}{$\begin{array}{c}\text { Bioenergy } \\
\text { productivity } \\
\left(\mathrm{L} \mathrm{CH}_{4} \mathrm{~L}^{-1} \mathrm{~d}^{-1}\right)\end{array}$} & \multicolumn{2}{|c|}{ Methane yield } \\
\hline & & & & & & & & & & $\left.\begin{array}{c}\left(\mathrm{L} \mathrm{CH}_{4}\right. \\
\text { g COD } \\
\text { rem. }\end{array}\right)$ & $\begin{array}{c}\text { ( } \mathrm{L} \mathrm{CH}_{4} \\
\text { g CODadd) }\end{array}$ \\
\hline \multirow[b]{2}{*}{1} & \multirow{2}{*}{$\begin{array}{c}22.9 \\
\pm 0.6^{\mathrm{b}} \\
(64)\end{array}$} & UASB1 & $\begin{array}{c}6.3 \\
\pm 1.5^{\mathrm{b}}(16)\end{array}$ & 4.0 & $\begin{array}{c}7.0 \\
\pm 0.1^{\mathrm{a}}(16)\end{array}$ & $\begin{array}{c}841 \\
\pm 142^{\mathrm{a}}(16)\end{array}$ & $\begin{array}{c}2062 \\
\pm 325^{\mathrm{b}}(16)\end{array}$ & $\begin{array}{c}71.3 \\
\pm 1.0^{\mathrm{a}}(58)\end{array}$ & $\begin{array}{c}0.50 \\
\pm 0.04^{\mathrm{b}}(58)\end{array}$ & $\begin{array}{c}0.19 \\
\pm 0.02^{\mathrm{a}}(25)\end{array}$ & $\begin{array}{c}0.10 \\
\pm 0.01^{\mathrm{a}}(58)\end{array}$ \\
\hline & & UASB2 & $\begin{array}{c}2.4 \\
\pm 1.7^{\mathrm{A}}(16)\end{array}$ & 8.0 & $\begin{array}{c}7.4 \\
\pm 0.1^{\mathrm{B}}(16)\end{array}$ & $\begin{array}{c}803 \pm 143^{\mathrm{A}} \\
(16)\end{array}$ & $\begin{array}{c}1981 \\
\pm 325^{\mathrm{A}}(16)\end{array}$ & $\begin{array}{c}69.4 \\
\pm 1.2^{\mathrm{A}}(41)\end{array}$ & $\begin{array}{c}0.05 \\
\pm 0.04^{\mathrm{A}}(41)\end{array}$ & $\begin{array}{c}0.08 \\
\pm 0.02^{\mathrm{A}}(40)\end{array}$ & $\begin{array}{c}0.01 \\
\pm 0.01^{\mathrm{A}}(41)\end{array}$ \\
\hline \multirow[b]{2}{*}{2} & \multirow{2}{*}{$\begin{array}{c}24.2 \\
\pm 0.8^{\mathrm{a}} \\
(34)\end{array}$} & UASB1 & $\begin{array}{c}14.2 \\
\pm 2.0^{\mathrm{a}}(11)\end{array}$ & 2.5 & $\begin{array}{c}7.2 \\
\pm 0.1^{\mathrm{a}}(11)\end{array}$ & $\begin{array}{c}696 \\
\pm 172^{\mathrm{a}}(11)\end{array}$ & $\begin{array}{c}3368 \\
\pm 412^{\mathrm{a}}(11)\end{array}$ & $\begin{array}{c}71.7 \\
\pm 1.3^{\mathrm{a}}(35)\end{array}$ & $\begin{array}{c}0.61 \\
\pm 0.05^{\mathrm{a}}(35)\end{array}$ & $\begin{array}{c}0.08 \\
\pm 0.02^{\mathrm{b}}(21)\end{array}$ & $\begin{array}{c}0.05 \\
\pm 0.01^{\mathrm{b}}(34)\end{array}$ \\
\hline & & UASB2 & $\begin{array}{c}5.0 \\
\pm 2.0^{\mathrm{A}}(11)\end{array}$ & 5.0 & $\begin{array}{c}7.6 \\
\pm 0.1^{\mathrm{A}}(11)\end{array}$ & $\begin{array}{c}501 \pm 180^{\mathrm{A}} \\
\quad(10)\end{array}$ & $\begin{array}{c}2345 \\
\pm 412^{\mathrm{A}}(10)\end{array}$ & $\begin{array}{c}67.6 \\
\pm 1.4^{A}(31)\end{array}$ & $\begin{array}{c}0.12 \\
\pm 0.06^{\mathrm{A}}(31)\end{array}$ & $\begin{array}{c}0.08 \\
\pm 0.02^{\mathrm{A}}(31)\end{array}$ & $\begin{array}{c}0.02 \\
\pm 0.01^{\mathrm{A}}(30)\end{array}$ \\
\hline
\end{tabular}

Different letters (Tukey test, $\mathrm{p}<0.05$ ) mean statistical difference.Comparisons between UASB1 (lowercase) and UASB2 (uppercase). (X) Number of samples for the calculation of the average. 
and the HTR was inferior. Nonetheless, such operating changes exerted no toxic effect on the microbial biomass, because the buffer capacity was maintained in both UASB reactors.

The minimal VFA consumptions were $1454 \mathrm{mg} \mathrm{L}^{-1}$ in UASB1 and $38 \mathrm{mg} \mathrm{L}^{-1}$ in UASB2, which revealed both UASB reactors were methanogenic, because VFA was consumed for the maintenance of the cellular metabolism and conversion of intermediate products $\left(\mathrm{H}_{2}, \mathrm{CO}_{2}\right.$ and acetate) to methane.

UASB1 was responsible for at least $83.6 \%$ of the total methane production in the system. Such performance was satisfactory, as it demonstrated the microorganism's adaptability to the application of a high OLR. On the other hand, UASB2 showed lower VFA consumption and an effluent with minimal $501 \mathrm{mg}$ VFA L ${ }^{-1}$. Some VFAs, such as propionate and butyrate, might be present in the influent of UASB2. The reactions of such acids are thermodynamically unfavorable for their transformation into acetate $\left(\Delta \mathrm{G}^{\circ}(\mathrm{kj})=+76.1\right.$ from propionate and +48.1 from butyrate to acetate) (Harper and Pohland, 1986), which may produce low methane yields. Similarly, methanogenic archaea do not use propionate and butyrate for methane production; therefore, a syntrophic association with acetogenic bacteria is required.

The association between methanogenic and acetogenic microorganisms was observed in UASB1 and UASB2, as a consequence of the application of a HRT higher than the time of growth of methanogenic organisms, such as Methanothrix of $6.9 \mathrm{~h}$ (maximum growth rate, $\mu_{\max }=0.1 \mathrm{~h}^{-1}$ ) (Harper and Pohland, 1986). The metabolic phases could be separated through the kinetic control and the washing of methanogenic microorganisms (Pohland and Ghosh, 1971). However, the conditions applied increased the HRT for a higher hydrolysis of the polymeric material present in the DMW and the metabolic phases were not separated.
Because of the metanogenenic activity in both UASB reactors, the methane production in the biogas was higher than $67 \%$ (Figure 2), which is significant $(\alpha=0.5)$ for experiments 1 and 2, even with an HRT decrease from 12 to $7.5 \mathrm{~d}$ (Table 2 and Figure 2). A maximum 4\% difference between UASB1 and UASB2 demonstrated their ability to produce biogas with high methane content for energy reuse.

Likewise, the amount of methane produced increased in experiment 2 (Table 2 and Figure 3) with bioenergy productivities of $0.61 \mathrm{~L} \mathrm{CH}_{4} \mathrm{~L}^{-1} \mathrm{~d}^{-1}$ in UASB1 and 0.12 $\mathrm{L} \mathrm{CH}_{4} \mathrm{~L}^{-1} \mathrm{~d}^{-1}$ in UASB2. Such a result was due to the adaptation of the system to the increase in the OLR, which led to the elevation of BA, reduction in VFA and consumption of COD. This adaptation was significant, because it did not affect the quality and amount of methane produced.

Therefore, HRT can be reduced to 7.5 days without affecting the methane production. The HRT reduction in UASB reactors is more advantageous than the high HRT commonly applied to biodigesters for the anaerobic treatment of DMW.

The methane yield was compared to the stoichiometric amount of $0.35 \mathrm{~L} \mathrm{CH}_{4} \mathrm{~g}^{-1} \mathrm{COD}$. However, the conversion of the organic matter to methane in the reactors achieved maximum efficiencies of $54.3 \%$ for UASB1 and $22.8 \%$ for UASB2, which were lower in relation to the organic matter added (Table 2). The low conversion of COD to methane might be due to the lignocellulosic material present in the animal feed. DMW contains fiber and polymers, which hamper its anaerobic degradation. Under such conditions, the hydrolytic phase is the limiting step (Ogejo and $\mathrm{Li}$, 2010; Rico et al., 2011a).

Similarly, a low VFA conversion to methane might be a consequence of thermodynamic inhibition, with a possible accumulation of propionate and butyrate. The separation of hydrolytic/acidogenic and methanogenic phases in different

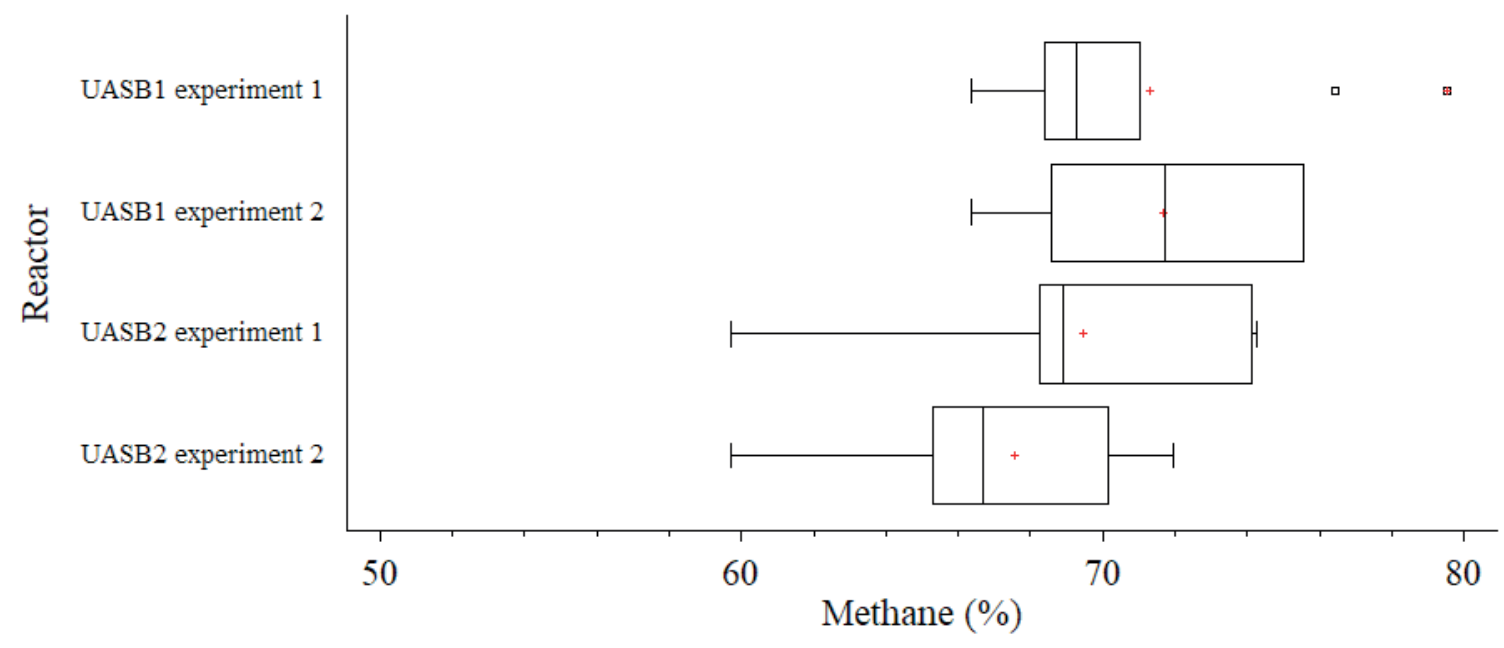

Figure 2. Methane production (\%) by a two serial UASB reactors. 


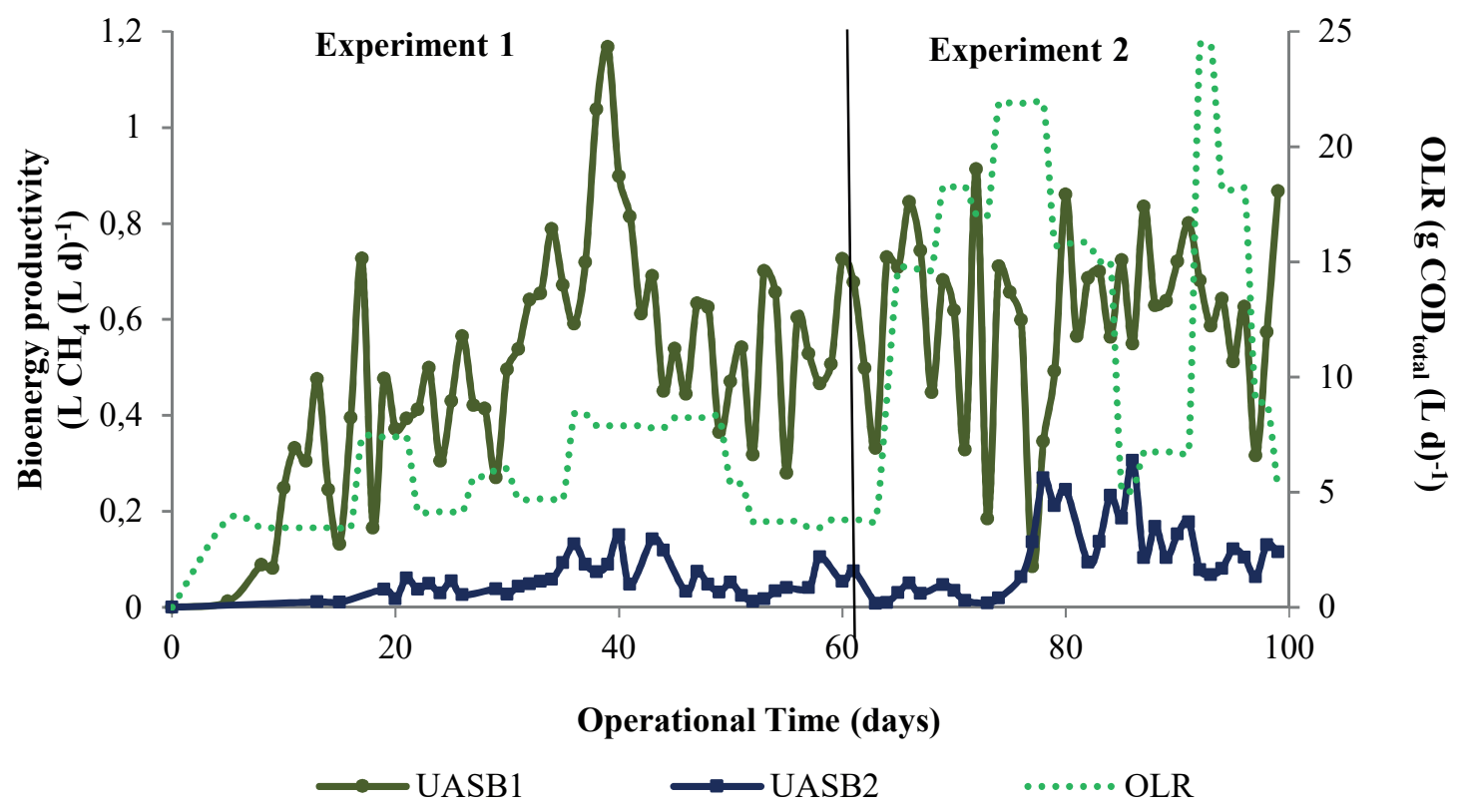

Figure 3. Bioenergy productivity and OLR during the operation of two serial UASB reactors.

reactors (two-stage configuration) could enable superior methane productions. During the physical separation of metabolism, the growth kinetics are favored, according to the nutritional conditions and velocity of duplication of each microbial group (Zoetemeyer et al.,1982).

Harper and Pohland (1986) described the anaerobic digestion as symbiotic associations between different groups of bacteria, in which the reaction is maintained through the continual removal of some products, such as hydrogen. Hydrogen can be removed through the separation of the reactor into two phases, so that the acetic acid pathway becomes favorable. Consequently, superior hydrolysis and acetogenesis are promoted, and, with an increased acetate production, the methane yield can be higher.

Demirer and Chen (2005) compared a single stage with two-stage UASB reactors. The conditions applied were unscreened dairy manure, mesophilic temperature, HRT of 10 days and OLR between 5 and $6 \mathrm{~kg} \mathrm{VS} \mathrm{m}^{-3} \mathrm{~d}^{-1}$. The authors obtained a 50 to $67 \%$ higher biogas production with a two-stage configuration (Demier and Chen, 2005).

In experiment 2 , the methane yield was reduced to 0.08 $\mathrm{LCH}_{4} \mathrm{~g} \mathrm{COD}_{\text {rem. }}{ }^{-1}$, which represents half of that obtained in experiment 1 (Table 1). The same effect was observed by Arikan et al. (2015), who achieved a 0.26 to $0.16 \mathrm{~m}^{3} \mathrm{~kg}^{-1}$ VS decrease in the methane yield when the OLR increased from 1.4 to $2.6 \mathrm{~kg} \mathrm{VS} \mathrm{m} \mathrm{d}^{-3} \mathrm{~d}^{-1}$ in a biodigester operating at $22^{\circ} \mathrm{C}$ and 17 days HRT. A large quantity of fibers was detected in the solid fraction, which is more difficult to degrade and be converted to methane (Arikan et al., 2015 and Moset et al., 2015).

For an increase in the substrate biodegradability, the DMW must be pretreated through sieving, so that the particle size is reduced and the fibrous material is retained (Rico et al., 2011a). The pretreatment technique alone is not enough in comparison with the flocculation and sieving adopted by Rico et al. (2011a). The authors operated the UASB reactor with the liquid fraction and obtained superior methane yield results of $0.28 \mathrm{~L} \mathrm{CH}_{4} \mathrm{~g}$ $\mathrm{COD}_{\text {add. }}{ }^{-1}$ and bioenergy productivity of $14 \mathrm{~L} \mathrm{CH}_{4} \mathrm{~L}^{-1} \mathrm{~d}^{-1}$. Although the physical-chemical pretreatment must be applied for improvements, the costs, technical expertise, and operational stages must also be considered. Therefore, the development of simple technologies is fundamental for the maximum exploitation of the raw residue and a high methane yield.

Witarsa and Lansing (2015) reported a superior methane yield, i.e.,0.27 and $0.42 \mathrm{~L} \mathrm{CH}_{4} \mathrm{~g} \mathrm{COD}_{\text {add. }}{ }^{-1}$, but at a higher HRT, i.e.,216 days. Nevertheless, the two serial UASB system showed a favorable conversion of organic matter to methane when the DWM was sieved, even with low HRT (7.5 days), high OLR (14.2 g CODL $^{-1} \mathrm{~d}^{-1}$ ) and no temperature control during the operation, which highlighted the ability of high-rate systems to achieve superior performance and time optimization.

\section{Removal of organic material from dairy manure wastewater}

Organic matter, such as chemical oxygen demand (COD), total suspended solids (TSS) and volatile suspended solids (SSV) are the elements found in high concentrations in the DMW; therefore, their removal in the UASB reactors is desirable. Table 3 and Figure 4 show the organic matter concentration in both influent and effluent. 
Table 3. Removal of organic material in the two serial UASB reactors.

\begin{tabular}{|c|c|c|c|c|c|c|c|c|}
\hline & \multicolumn{4}{|c|}{ Experiment 1} & \multicolumn{4}{|c|}{ Experiment 2} \\
\hline & Influent & Effluent UASB1 & UASB2 & $\begin{array}{c}\text { Removal } \\
\text { UASB1 + } \\
\text { UASB2 }\end{array}$ & Influent & Effluent UASB1 & UASB2 & $\begin{array}{c}\text { Removal } \\
\text { UASB1 + } \\
\text { UASB2 }\end{array}$ \\
\hline & \multicolumn{3}{|c|}{$\mathbf{m g ~ L ^ { - 1 }}$} & $(\%)$ & \multicolumn{3}{|c|}{$\mathrm{mg} \mathrm{L}^{-1}$} & $(\%)$ \\
\hline COD & $\begin{array}{c}25117 \\
\pm 4355^{\mathrm{a}}(19)\end{array}$ & $\begin{array}{c}19314 \\
\pm 4745^{\wedge}(16)\end{array}$ & $\begin{array}{c}6790 \\
\pm 4901^{\mathrm{a}}(15)\end{array}$ & $\begin{array}{c}72.2 \\
\pm 7.9^{\Perp}(15)\end{array}$ & $\begin{array}{c}35548 \\
\pm 5723^{\mathrm{a}}(11)\end{array}$ & $\begin{array}{c}25006 \\
\pm 5723^{\mathrm{A}}(11)\end{array}$ & $\begin{array}{c}9839 \\
\pm 5723^{\mathrm{a}}(11)\end{array}$ & $\begin{array}{c}73.3 \\
\pm 9.6^{ \pm}(10)\end{array}$ \\
\hline TSS & $\begin{array}{c}16568 \\
\pm 24497^{\mathrm{a}}(15)\end{array}$ & $\begin{array}{c}155453 \\
\pm 24497^{\mathrm{A}}(15)\end{array}$ & $\begin{array}{c}3558 \\
\pm 25356 \mathrm{a}(14)\end{array}$ & $\begin{array}{c}74.5 \\
\pm 11.7 \stackrel{\mathrm{A}}{(}(14)\end{array}$ & $\begin{array}{c}23834 \\
\pm 28606^{\mathrm{a}}(11)\end{array}$ & $\begin{array}{c}84011 \\
\pm 28606^{\mathrm{B}}(11)\end{array}$ & $\begin{array}{c}5303 \\
\pm 28606^{\mathrm{a}}(11)\end{array}$ & $\begin{array}{c}71.2 \\
\pm 13.2^{\Perp}(11)\end{array}$ \\
\hline VSS & $\begin{array}{c}14040 \\
\pm 18304^{\mathrm{a}}(115)\end{array}$ & $\begin{array}{c}115473 \\
\pm 18305^{\mathrm{A}}(15)\end{array}$ & $\begin{array}{c}2595 \\
\pm 18304^{\mathrm{a}}(11)\end{array}$ & $\begin{array}{c}78.6 \\
\pm 10.8^{ \pm}(14)\end{array}$ & $\begin{array}{c}19203 \\
\pm 21374^{\mathrm{a}}(11)\end{array}$ & $\begin{array}{c}64583 \\
\pm 21374^{A}(11)\end{array}$ & $\begin{array}{c}3808 \\
\pm 21374^{\mathrm{a}}(11)\end{array}$ & $\begin{array}{c}74.2 \\
\pm 12.6^{\mathrm{A}}(11)\end{array}$ \\
\hline
\end{tabular}

Different letters (Tukey test, $\mathrm{p}<0.05$ ) mean statistical difference.Comparisons between influents (lowercase), UASB1 (uppercase) and UASB2 (underline lowercase). (X) Number of samples for the calculation of the average.

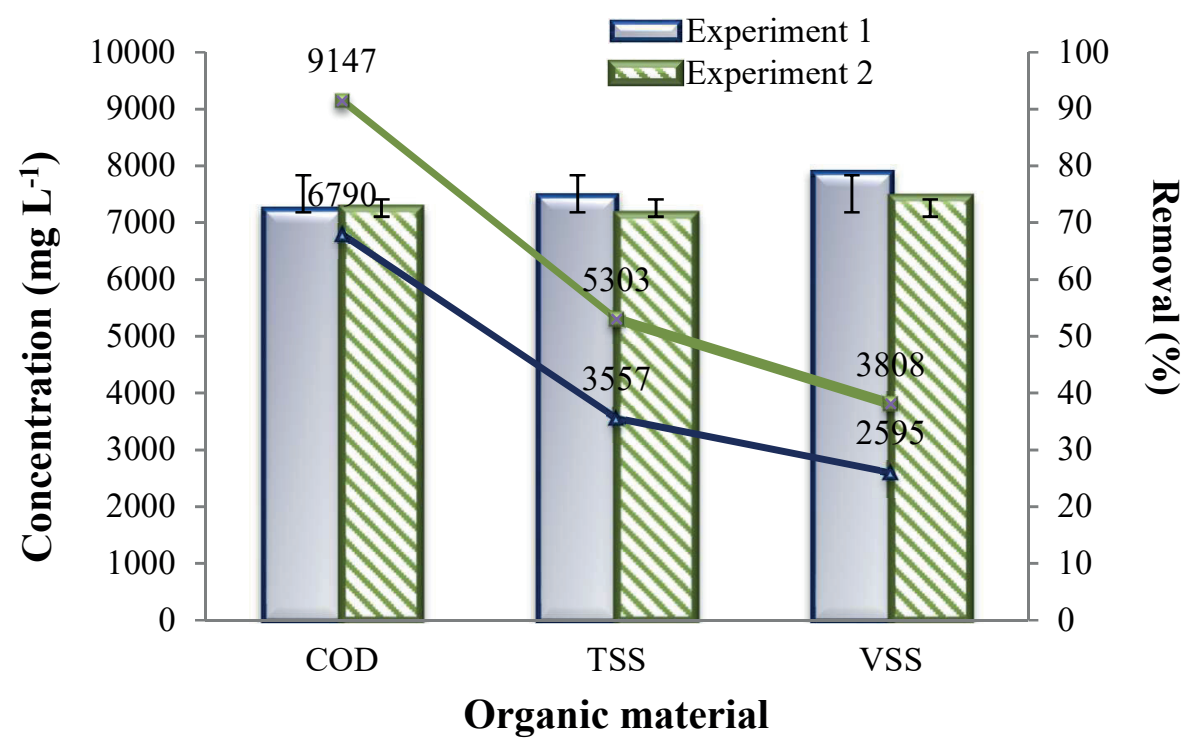

Figure 4. Performance of the two serial UASB reactors in the removal and organic materials (COD, TSS and VSS).

TSS values of 16568 and $23834 \mathrm{mg} \mathrm{L}^{-1}$ and VSS of 14040 and $19302 \mathrm{mg} \mathrm{L}^{-1}$ were obtained in the effluents for experiments 1 and 2, respectively, which indicates over $80 \%$ are volatile organic matter; therefore, they are more easily degraded and converted to methane. Approximately $66 \%$ of COD consists of suspended solids, which implies hydrolysis is the limiting phase for the supply of dissolved material available for the microorganism consumption during anaerobic digestion.

Under such substrate conditions, the COD, TSS and VSS removals were higher than $71 \%$ and showed no significant statistical difference between experiments 1 and 2. Therefore, either the reactor scale can be decreased 1.6 times, or the OLR can be increased up to 2.2 times without affecting the UASB reactor performance during the organic matter removal, as observed in experiment 2. UASB2 contributed to such efficiencies, as it retained the excess sludge washed out from UASB1 and improved the quality of the effluents. Therefore, the use of serial highrate reactors is recommended for the treatment of highly concentrated substrates.

The DMW characteristics are highly variable, as the COD values range from 10220 to $55900 \mathrm{mg} \mathrm{L}^{-1}$ (Nikolaeva et al., 2013, Rico et al., 2011a). Such a variation depends on the number of animals per space unit, amount of water used for cleaning the barn, washing techniques and influent pretreatment.

The removals of COD by a treatment system composed of two serial UASB reactors and wetland achieved $86 \%$ and $81 \%$, respectively, which demonstrates that high-rate reactors offer technological advantages, because they provide higher efficiencies with low HRT (7.5 days), in comparison to wetland (22.5 days) (Adhikari et al., 2015; Rico et al., 2011a). 
The effluent from the two serial UASB system showed organic matter concentrations between 6790 and $9839 \mathrm{mg} \mathrm{L}^{-1}$ of COD and neutral $\mathrm{pH}$ (between 7.4 and 7.6), which could be explored for irrigation (Möller and Müller, 2012) or reduction in the water consumption during forage growth.

\section{Characterization of dairy manure wastewater after anaerobic treatment}

The characterization of the effluent from UASB reactors was evaluated according to important elements recognized as nutrients for the agricultural sector (Table 4 and Figure 5) that show the effluent can potentially fertilize plants. During experiment 2, the concentration of most nutrients was high, due to the superior solids application in the reactors (Sakar et al., 2009).

The concentrations of macro- and micronutrients in the influent varied in comparison to other studies (Adhikari et al., 2015; Page et al., 2015; Rico et al., 2011b), because of differences in the composition of the animal food, productivity, cattle age, management of waste from bedding and the cleaning technique of the confinement area (Caiet al., 2013; Rico et al., 2011b). The use of a raw substrate may have caused the differences in the nutrient concentrations in the effluents, as observed during experiments 1 and 2 and substrates with similar COD.

High concentrations of TKN and N-am, i.e., 642 and 1004 $\mathrm{mg} \mathrm{L}^{-1}$ and 153 and $306 \mathrm{mg} \mathrm{L}^{-1}$, respectively, are also present in DMW. The removals of TKN by the UASB1+UASB2 system achieved $23.9 \%$ in experiment 1 and $49.1 \%$ in experiment 2 . Nevertheless, the concentration of TKN increased in UASB1 due to sludge washout, the ammonification phenomenon and an increased concentration of $\mathrm{N}$-am in the effluents, with values of 304 and $522 \mathrm{mg} \mathrm{L}^{-1}$ in experiments 1 and 2, respectively.

UASB2 removed $23.9 \%$ and $49.1 \%$ of TKN in experiments 1 and 2. Consequently, the effluent showed a higher nitrogen concentration in the soluble form of $\mathrm{N}$-am, which could be interesting for plants, since the aim is the use of the effluent for fertigation (Prieto et al., 2013). The nitrogen removal was justified by the minimal use of nitrogen for cellular biosynthesis during the anaerobic digestion (Möller and Müller, 2012).

TP showed importantremoval efficiency during the UASB systems operation, with values of $63.3 \%$ and $27.5 \%$

Table 4. Removal of macro and micronutrients by two serial UASB reactors.

\begin{tabular}{|c|c|c|c|c|c|c|c|c|}
\hline & \multicolumn{4}{|c|}{ Experiment 1} & \multicolumn{4}{|c|}{ Experiment 2} \\
\hline & Influent & $\begin{array}{l}\text { Effluent } \\
\text { UASB1 }\end{array}$ & UASB2 & $\begin{array}{c}\text { Removal } \\
\text { UASB1+ } \\
\text { UASB2 }\end{array}$ & Influent & $\begin{array}{l}\text { Effluent } \\
\text { UASB1 }\end{array}$ & UASB2 & $\begin{array}{c}\text { Removal } \\
\text { UASB1+ } \\
\text { UASB2 }\end{array}$ \\
\hline & \multicolumn{3}{|c|}{$\mathbf{m g} \mathbf{L}^{-1}$} & $(\%)$ & \multicolumn{3}{|c|}{$\mathbf{m g ~ L ^ { - 1 }}$} & $(\%)$ \\
\hline \multicolumn{9}{|c|}{ Macronutrients } \\
\hline TKN & $\begin{array}{c}642.1 \\
\pm 248.4^{\mathrm{a}}(8)\end{array}$ & $\begin{array}{c}754.7 \\
\pm 234.2^{\mathrm{A}}(9)\end{array}$ & $\begin{array}{c}474.2 \\
\pm 248.4^{\mathrm{a}}(8)\end{array}$ & $\begin{array}{c}23.9 \\
\pm 18.2^{\mathrm{A}}(8)\end{array}$ & $\begin{array}{c}1004.0 \\
\pm 314.2^{\mathrm{a}}(5)\end{array}$ & $\begin{array}{c}1238.5 \\
\pm 314.2^{\mathrm{A}}(5)\end{array}$ & $\begin{array}{c}521.4 \\
\pm 314.2 \mathrm{a}(5)\end{array}$ & $\begin{array}{c}49.1 \\
\pm 23.0^{\mathrm{A}}(5)\end{array}$ \\
\hline N-am. & $\begin{array}{c}153.5 \\
\pm 45.9^{\mathrm{b}}(16)\end{array}$ & $\begin{array}{c}304.3 \\
\pm 45.9^{\mathrm{B}}(15)\end{array}$ & $\begin{array}{c}356.5 \\
\pm 45.9 \mathrm{a}(14)\end{array}$ & N.R & $\begin{array}{c}306.5 \\
\pm 53.6^{\mathrm{a}}(10)\end{array}$ & $\begin{array}{c}522.0 \\
\pm 56.2^{\mathrm{A}}(10)\end{array}$ & $\begin{array}{c}402.8 \\
\pm 53.6^{\mathrm{a}}(10)\end{array}$ & N.R \\
\hline $\mathbf{T P}$ & $\begin{array}{c}82.4 \\
\pm 16.2^{\mathrm{a}}(8)\end{array}$ & $\begin{array}{c}85.9 \\
\pm 15.3^{\mathrm{A}}(9)\end{array}$ & $\begin{array}{c}29.9 \\
\pm 16.2 \mathrm{a}(8)\end{array}$ & $\begin{array}{c}63.3 \\
\pm 29.1^{\mathrm{A}}(8)\end{array}$ & $\begin{array}{c}91.8 \\
\pm 20.5^{\mathrm{a}}(5)\end{array}$ & $\begin{array}{c}77.8 \\
\pm 20.5^{\mathrm{A}}(5)\end{array}$ & $\begin{array}{c}57.4 \\
\pm 22.9 \mathrm{a}(4)\end{array}$ & $\begin{array}{c}27.5 \\
\pm 41.2^{\mathrm{A}}(4)\end{array}$ \\
\hline $\mathbf{K}$ & $\begin{array}{c}10.4 \\
\pm 6.3^{\mathrm{a}}(10)\end{array}$ & $\begin{array}{c}11.3 \\
\pm 6.7^{\mathrm{A}}(9)\end{array}$ & $\begin{array}{c}12.1 \\
\pm 7.06 \mathrm{a}(8)\end{array}$ & N.R & $\begin{array}{c}18.3 \\
\pm 8.9^{\mathrm{a}}(5)\end{array}$ & $\begin{array}{c}23.1 \\
\pm 8.9^{\mathrm{A}}(5)\end{array}$ & $\begin{array}{c}23.4 \\
\pm 8.9 \mathrm{a}(5)\end{array}$ & N.R \\
\hline $\mathbf{C a}$ & $\begin{array}{c}10.6 \\
\pm 4.2^{\mathrm{a}}(10)\end{array}$ & $\begin{array}{c}12.4 \\
\pm 4.4^{\mathrm{A}}(9)\end{array}$ & $\begin{array}{c}5.9 \\
\pm 4.6 \mathrm{a}(8)\end{array}$ & $\begin{array}{c}43.4 \\
\pm 35.2^{\underline{A}}(8)\end{array}$ & $\begin{array}{c}18.2 \\
\pm 5.8^{\mathrm{a}}(5)\end{array}$ & $\begin{array}{c}16.5 \\
\pm 5.8^{\mathrm{A}}(5)\end{array}$ & $\begin{array}{c}8.5 \\
\pm 5.8^{\mathrm{a}}(5)\end{array}$ & $\begin{array}{c}20.4 \\
\pm 44.5^{\wedge}(5)\end{array}$ \\
\hline Mg & $\begin{array}{c}5.0 \\
\pm 1.2^{\mathrm{a}}(10)\end{array}$ & $\begin{array}{c}5.6 \\
\pm 1.2^{\mathrm{A}}(9)\end{array}$ & $\begin{array}{c}3.6 \\
\pm 1.9 \mathrm{a}(8)\end{array}$ & $\begin{array}{c}27.2 \\
\pm 17.2^{\mathrm{A}}(8)\end{array}$ & $\begin{array}{c}8.1 \\
\pm 1.7^{\mathrm{a}}(5)\end{array}$ & $\begin{array}{c}7.0 \\
\pm 1.7^{\mathrm{A}}(5)\end{array}$ & $\begin{array}{c}4.2 \\
\pm 1.7 \mathrm{a}(5)\end{array}$ & $\begin{array}{c}41.0 \\
\pm 12.6^{\mathrm{A}}(5)\end{array}$ \\
\hline $\mathbf{N a}$ & $\begin{array}{c}186.6 \\
\pm 58.8^{\mathrm{a}}(10)\end{array}$ & $\begin{array}{c}198.3 \\
\pm 62.0^{\mathrm{A}}(9)\end{array}$ & $\begin{array}{c}174.2 \\
\pm 65.8 \mathrm{a}(8)\end{array}$ & N.R & $\begin{array}{c}164.0 \\
\pm 83.2^{\mathrm{a}}(5)\end{array}$ & $\begin{array}{c}154.7 \\
\pm 83.2^{\mathrm{A}}(5)\end{array}$ & $\begin{array}{c}202.5 \\
\pm 83.2^{\mathrm{a}}(5)\end{array}$ & N.R \\
\hline \multicolumn{9}{|c|}{ Micronutrients } \\
\hline $\mathbf{F e}$ & $\begin{array}{c}77.0 \\
\pm 50.1^{\mathrm{a}}(10)\end{array}$ & $\begin{array}{c}96.2 \\
\pm 52.8^{\mathrm{A}}(9)\end{array}$ & $\begin{array}{c}21.7 \\
\pm 56.0 \mathrm{a}(8)\end{array}$ & $\begin{array}{c}69.2 \\
\pm 62.6^{\mathrm{A}}(8)\end{array}$ & $\begin{array}{c}160.2 \\
\pm 70.8^{\mathrm{a}}(5)\end{array}$ & $\begin{array}{c}166.0 \\
\pm 70.8^{\mathrm{A}}(5)\end{array}$ & $\begin{array}{c}68.5 \\
\pm 70.8 \mathrm{a}(5)\end{array}$ & N.R \\
\hline Zn & $\begin{array}{c}8.3 \\
\pm 17.1^{\mathrm{a}}(10)\end{array}$ & $\begin{array}{c}42.4 \\
\pm 18.1^{\mathrm{A}}(9)\end{array}$ & $\begin{array}{c}2.6 \\
\pm 19.2 \mathrm{a}(8)\end{array}$ & $\begin{array}{c}46.8 \\
\pm 180.4^{\mathrm{A}}(8)\end{array}$ & $\begin{array}{c}15.4 \\
\pm 24.2^{\mathrm{a}}(5)\end{array}$ & $\begin{array}{c}23.7 \\
\pm 24.2^{\mathrm{A}}(5)\end{array}$ & $\begin{array}{c}13.0 \\
\pm 24.2^{\mathrm{a}}(5)\end{array}$ & N.R \\
\hline Mn & $\begin{array}{c}11.2 \\
\pm 3.2^{\mathrm{a}}(10)\end{array}$ & $\begin{array}{c}12.5 \\
\pm 3.4^{\mathrm{A}}(9)\end{array}$ & $\begin{array}{c}6.2 \\
\pm 3.6^{\mathrm{a}}(8)\end{array}$ & $\begin{array}{c}43.9 \\
\pm 31.9 \AA \\
\end{array}$ & $\begin{array}{c}15.2 \\
\pm 4.5^{\mathrm{a}}(5)\end{array}$ & $\begin{array}{c}17.7 \\
\pm 4.55^{\mathrm{A}}(5)\end{array}$ & $\begin{array}{c}10.0 \\
\pm 4.5 \mathrm{a}(5)\end{array}$ & N.R \\
\hline
\end{tabular}

Different letters (Tukey test, $\mathrm{p}<0.05$ ) mean statistical difference.Comparisons between influents (lowercase), UASB1 (uppercase) and UASB2 (underline lowercase). (X) Number of samples for the calculation of the average.N.R: Not removal. 

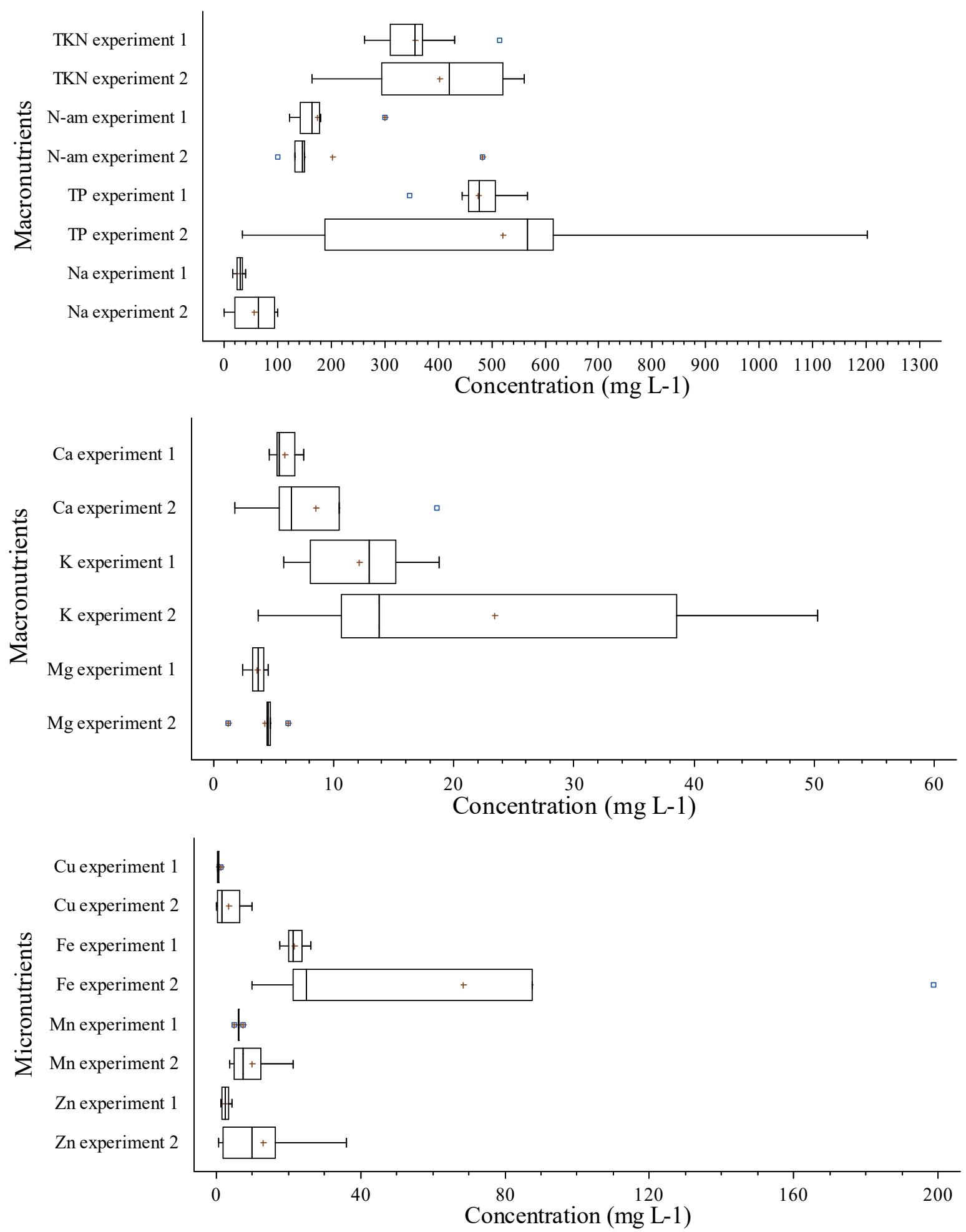

Figure 5. Macro- (TKN, $\mathrm{N}$-am, $\mathrm{TP}, \mathrm{K}, \mathrm{Ca}, \mathrm{Mg}$ and $\mathrm{Na}$ ) and micronutrients (Fe, $\mathrm{Zn}, \mathrm{Mn}$ and $\mathrm{Cu}$ ) in the effluent of two serial UASB reactors.

in experiments 1 and 2, respectively, and could be used in microbial activities in reactors as a substrate for the syntheses of adenylates, nucleic acids and phospholipids (Möller and Müller, 2012).
Nitrogen, phosphorous and $\mathrm{K}$ are important nutrients that can improve soil productivity, therefore, the liquid and sludge effluent from the anaerobic reactors are a valuable source for the agricultural sector (Sakar et al., 2009). 
$\mathrm{K}, \mathrm{Ca}$ and $\mathrm{Mg}$ are also keycompounds for the anaerobic digestion of microorganisms. Their concentrations in the influent ranged between 3.6 and $23.4 \mathrm{mg} \mathrm{L}^{-1}$ and their maximal removal was $43 \%$ in the serial UASB reactors (Figure 5). The nutrients removal may have been caused by the cellular synthesis and/or physical-chemical processes, such as precipitation and sludge adsorption (Möller and Müller, 2012). Consequently, their concentrations in the effluent did not exceed $23.4 \mathrm{mg} \mathrm{L}^{-1}$ (Table 4). $\mathrm{Ca}$ and $\mathrm{Mg}$ are required by crops in substantial amounts (Sakar et al., 2009); therefore, the effluent could be reused as a source of such a nutrient.

The $\mathrm{Na}$ concentrations in the influent may have originated from animal food in the cattle production. Low or no removal of $\mathrm{Na}$ was obtained by the serial UASB reactors due to their low ability for nutrient removal from DMW in anaerobic processes. The high solubility of $\mathrm{Na}$ in the liquid prevents its sedimentation in the sludge and increases its concentrations in the effluent (Duda, 2010). Therefore, lower Na concentrations could be applied to animal food, because of the difficulty of removal from biological systems and potential negative impacts on the soil salinization during re-use in fertigation. As a consequence, a further treatment of the effluent is necessary for the removal of excess $\mathrm{Na}$.

$\mathrm{Fe}, \mathrm{Zn}, \mathrm{Mn}$ and $\mathrm{Cu}$ were also present in the influent (Table 4), probably due to the diet, dietary supplements, and water consumed by animals, and eliminated as urine and feces (Sakar et al., 2009). For example, $\mathrm{Cu}$ and $\mathrm{Zn}$ are supplemented as trace metals in transition dairy cows, as promoters of the antioxidant and immunity system (Spears and Weiss, 2008). Some products such as $\mathrm{Cu}$ proteinate, $\mathrm{Cu}$ sulfate, $\mathrm{Zn}$ methionine, and $\mathrm{Zn}$ proteinate (Spears and Weiss, 2008) used for animal growth could be a source of metals in the manure. Their presence during the anaerobic digestion is important for the cellular growth, because they act as coenzymes or cofactors (Manyi-Loh et al., 2013).

$\mathrm{Fe}$ was the nutrient of highest removal by the anaerobic system, probably due to the formation of phosphate $\left(\mathrm{Fe}_{3}\left(\mathrm{PO}_{4}\right)_{2}\right)$, hydroxides $\left(\mathrm{Fe}(\mathrm{OH})_{2}\right)$ or carbonate $\left(\mathrm{FeCO}_{3}\right)$ retained in the sludge (Möller and Muller, 2012; Page et al., 2015). However, no metal characterization in the sludge was performed for the confirmation of such a hypothesis.

$\mathrm{Zn}, \mathrm{Mn}$ and $\mathrm{Cu}$ exert a positive effect on the anaerobic digestion, as they increase the methane production, substrate utilization, and reactor stability (Manyi-Loh et al., 2013). However, the presence of nutrients may not be correlated with the methane biosynthesis, since both influents showed similar quantities of the aforementioned elements (Table 2 and 3). Low concentrations were detected in the effluent, which is a positive result, since metals such as $\mathrm{Fe}$ and $\mathrm{Cu}$ can accumulate in agricultural soils (Sheets et al., 2015).

At least $30.8 \%$ of the nutrients quantified in the substrate of the system were found in the effluent and could be recycled (Figure 5). No significant difference was observed between the experiments, which proved HRT exerted no effect on the removal of the macro- and micronutrients. Similar results were reported by Castrillón et al. (2002) during the treatment of cattle manure in UASB reactors for HRT between 22.5 and 7.3 days. The authors concluded the metals removal was not related to the HRT. Fe was the micronutrient of higher concentration in cattle manure and the anaerobic system removed a minimal of $50.4 \%$ of this metal.

Experiment 2 showed no removal of $\mathrm{K}, \mathrm{Na}, \mathrm{Fe}, \mathrm{Zn}$ and $\mathrm{Cu}$, probably as a consequence of the sludge washing evidenced by the reduction of solids in some sludge sampling points of the reactor (data not shown). Sludge can accumulate nutrients and cations and be used as a potential substrate source for microbial activities and a stimulator in the sludge granulation process (Annachhatre and Bhamidimarri, 1992). Thereby, when the sludge is washed out from the reactors, the concentration of the nutrients in the liquid effluent increases.

Similar performances were reported by Ogejo and $\mathrm{Li}$ (2010), who studied the treatment of DMW in co-digestion with turkey processing wastewater in an attached growth digester. They observed small changes in the $\mathrm{K}, \mathrm{Ca}, \mathrm{Mg}$, $\mathrm{Zn}, \mathrm{Cu}, \mathrm{Mn}$ and $\mathrm{Na}$ concentrations; however, such elements exerted no direct effect on the biogas production.

The Brazilian Regulation (Normative Instruction No. 25 of July $23^{\text {rd }}, 2009$ ) allows the controlled application of effluents from animal wastes in soil and crops. The minimal concentrations in the fluid product of $\mathrm{Ca}, \mathrm{Mg}, \mathrm{Cu}$, $\mathrm{Mn}$ and $\mathrm{Zn}$ for soil application are 5000, 5000, 500, 500, and $500 \mathrm{mg} \mathrm{L}^{-1}$, and 3000, 3000, 500, 200 and $500 \mathrm{mg} \mathrm{L}^{-1}$ for foliar application or fertigation, respectively. A minimal soluble concentration in water for nitrogen is $10000 \mathrm{mg}$ $\mathrm{L}^{-1}$. All elements referenced by the Brazilian Regulation were observed in the effluent from serial UASB reactors, however, in inferior concentrations. Therefore, DMW can potentially be reused in fertigation and a higher OLR could be applied in the anaerobic systems for the achievement of the minimal nutrients concentrations required in fluid products.

The effluent of the two serial UASB systems and a commercial fertilizer, NPK 04-14-08 (applied over forage $B$. brizantha used for cattle dairy nutrition) were compared. Only $70 \mathrm{~L} \mathrm{ha}^{-1}$ of the effluent of experiment 2 are required for the same amount of nitrogen, phosphorous and potassium available for fertilizer NPK 04-14-08, with $571.4 \mathrm{~kg} \mathrm{ha}^{-1}$ (Lima et al., 2010). The UASB system tested could irrigate up to 3.4 hectares monthly and 41.4 hectares annually, which mean significant savings for farmers could be achieved by the setting-up of full scale reactors.

The two serial UASB system produces energy and an effluent from DMW containing macro and micronutrients and low concentrations of organic matter. The effluent could be a source of nutrients for fertigation. However, a post-treatment is required for the removal of sodium and microorganisms. 


\section{Sludge from serial UASB reactors during anaerobic treatment}

The sludge from UASB reactors was evaluated by a VS/TS relation at different sampling points (Table 5), with values between 0.65 and 0.73 for experiments 1 and 2 . TS and VS increased in experiment 2, probably due to the accumulation of solids in the reactor by the cell growth and precipitation of organic and inorganic compounds, as explained in previous sections.

UASB1 showed sludge washout during the operational period. In contrast, UASB2 was effective in retaining the excess sludge and providing superior effluent quality.
The sludge retention in the second reactor sustains the importance of serial UASB reactors in the overall performance.

The reuse of the anaerobic sludge from the two serial UASB reactors was evaluated according to the Brazilian Regulation (CONAMA 375), which has established that sludge can be reused for agricultural purposes when the VS/TS relation is lower than 0.7 . This value indicates organic matter stabilization and avoids high microbial activities when sludge is applied to soils (CONAMA, 2006). Both reactors produced organic fertilizers due to the active biomass present in the sludge adapted for the loading of organic shocks (Latif et al., 2011).

Table 5. Solids in the anaerobic sludge of the serial UASB reactors.

\begin{tabular}{|c|c|c|c|c|}
\hline \multirow[b]{3}{*}{$\begin{array}{l}\text { Experiment } \\
\text { Sample points }\end{array}$} & \multicolumn{4}{|c|}{ VS/TS } \\
\hline & \multicolumn{2}{|c|}{ UASB1 } & \multicolumn{2}{|c|}{ UASB2 } \\
\hline & 1 & 2 & 1 & 2 \\
\hline 1 & $0.73 \pm 0.05^{\mathrm{a}}(4)$ & $0.69 \pm 0.03^{\mathrm{a}}(2)$ & $0.65 \pm 0.06^{\mathrm{a}}(4)$ & $0.71 \pm 0.07^{\mathrm{a}}(2)$ \\
\hline 2 & $0.73 \pm 0.05^{\mathrm{A}}(4)$ & $0.69 \pm 0.08^{\mathrm{A}}(2)$ & $0.67 \pm 0.06^{\mathrm{A}}(4)$ & $0.71 \pm 0.07^{\mathrm{A}}(2)$ \\
\hline 3 & $0.73 \pm 0.05 \mathrm{a}(4)$ & $0.73 \pm 0.07 \mathrm{a}(2)$ & $0.69 \pm 0.06^{\mathrm{a}}(4)$ & $0.71 \pm 0.07^{\mathrm{a}}(2)$ \\
\hline 4 & $0.72 \pm 0.05^{\mathrm{A}}(4)$ & $0.73 \pm 0.07 \stackrel{\mathrm{A}}{(2)}$ & $0.71 \pm 0.05^{\mathrm{A}}(4)$ & $0.71 \pm 0.07^{\mathrm{A}}(2)$ \\
\hline
\end{tabular}

Different letters (Tukey test, $\mathrm{p}<0.05$ ) mean statistical difference. Comparisons between reactor points 1 (uppercase) and 2 (lowercase) for UASB1 and UASB2 separately. (X) Number of samples for the calculation of the average.

\section{CONCLUSIONS}

Dairy manure wastewater treated in two serial UASB reactors showed a maximum bioenergy productivity of $0.73 \mathrm{~L} \mathrm{CH}_{4} \mathrm{~L}^{-1} \mathrm{~d}^{-1}$ and maximal methane yield of $0.19 \mathrm{~L}$ $\mathrm{CH}_{4} \mathrm{~g} \mathrm{COD}_{\text {rem. }}^{-1}$ with superior methane production in UASB1. The methane yields were low in both reactors; therefore, superior performance could be achieved through the separation of the metabolic phases.

High removals of COD, SST and SSV between 71.2 and $78.6 \%$ produced at a 7.5 day HRT showed the capacity of the system to replace conventional systems, such as anaerobic biodigesters.

Nutrients, such as nitrogen, phosphorus, $\mathrm{K}, \mathrm{Ca}, \mathrm{Mg}$, $\mathrm{Na}, \mathrm{Fe}, \mathrm{Zn}, \mathrm{Mn}$ and $\mathrm{Cu}$ were found in the effluent of the serial UASB system. The content of nitrogen, phosphorous and $\mathrm{K}$ in the effluent showed potential for agricultural fertigation; however, the high Na concentration present in the DMW represents a risk for soil application.

Sludge from the UASB reactors showed appropriate characteristics for the soil fertilization, according to the Brazilian Regulation, and a potential by-product for application in forage plants.

\section{ACKNOWLEDGEMENTS}

The authors acknowledge the financial support provided by CAPES agency.

\section{NOMENCLATURE}

BA - Bicarbonate alkalinity, $\mathrm{mg} \mathrm{L}^{-1}$.

COD - Chemical oxygen demand, $\mathrm{mg} \mathrm{L}^{-1}$.

CSTR - Continuous Stirred Tank Reactors.

DMW - Dairy manure wastewater.

HRT - Hydraulic retention time, d.

IA - Intermediate alkalinity, $\mathrm{m} \mathrm{L} \mathrm{L}^{-1}$.

$\mathrm{N}$-am - Ammonia nitrogen, $\mathrm{mg} \mathrm{L}^{-1}$.

OLR - Organic load rate, g COD ${ }_{\text {total }} \mathrm{L}^{-1} \mathrm{~d}^{-1}$.

PA - Partial alkalinity, $\mathrm{mg} \mathrm{L}^{-1}$.

TA -Total alkalinity, $\mathrm{mg} \mathrm{L}^{-1}$.

TKN - Total Kjeldahl nitrogen, $\mathrm{mg} \mathrm{L}^{-1}$.

TP - Total phosphorus, $\mathrm{mg} \mathrm{L}^{-1}$.

TS - Total solids, $\mathrm{mg} \mathrm{L}^{-1}$.

TSS - Total suspended solids, $\mathrm{mg} \mathrm{L}^{-1}$.

UASB - Upflow Anaerobic Sludge Blanket.

VFA - Volatile fatty acids, $\mathrm{mg} \mathrm{L}^{-1}$. 
VS - Volatile solids, $\mathrm{mg} \mathrm{L}^{-1}$ VSS - Volatile suspended solids, $\mathrm{mg} \mathrm{L}^{-1}$.

\section{REFERENCES}

Adhikari, U., Harrigan, T., and Reinhold, D. M., Use of duckweed-based constructed wetlands for nutrient recovery and pollutant reduction from dairy wastewater. Ecological Engineering, 78, 6 (2015).

Annachhatre, A. P., and Bhamidimarri, S. M., Microbial attachment and growth in fixed-film reactors: process startup considerations. Biotechnology Advances, 10, 69 (1992).

Appels, L., Lauwers, J., Degrève, J., Helsen, L., Lievens, B., Willems, K., Impe, J.V., and Dewil, R., Anaerobic digestion in global bio-energy production: potential and research challenges. Renewable and Sustainable Energy Reviews, 15, 4295 (2011).

Arikan, O. A., Mulbry, W., and Lansing, S., Effect of temperature on methane production from field-scale anaerobic digesters treating dairy manure. Waste Management, 43, 108 (2015).

APHA, Standard Methods for the Examination of Water and Wastewater. 21st Ed., (2005).

Cai, T., Park, S. Y., and Li, Y., Nutrient recovery from wastewater streams by microalgae : Status and prospects. Renewable and Sustainable Energy Reviews, 19, 360 (2013).

Castrillón, L., Vázquez, I., Marañón, E., and Sastre, H., Anaerobic thermophilic treatment of cattle manure in UASB reactors. Waste Management \& Research, 20, 350 (2002).

Conselho Nacional do Meio Ambiente (CONAMA 375)., Define critérios e procedimentos, para o uso agrícola de lodos de esgoto gerados em estações de tratamento de esgoto sanitário e seus produtos derivados, e dá outras providências (2006).

Demirer, G. N., and Chen, S.,Two-phase anaerobic digestion of unscreened dairy manure. Process Biochemistry, 40, 3542 (2005).

DiLallo, R., and Albertson, O. E., Volatile acids by direct titration. Journal Water Pollution Control Federation, 33, 356 (1961).

Duda, R. M., Desempenho de sistema composto por reatores anaeróbios em série seguido de filtro biológico percolador no tratamento de águas residuárias de suinocultura. Ph.D. These, São Paulo State University - Jaboticabal, (2010).

Harper, S. R., and Pohland, F. G., Recent developments in hydrogen management during anaerobic biological wastewater treatment. Biotechnology and Bioengineering, 28, 585 (1986).

Jenkins, S. R., Morgan, J. M., and Sawyer, C. L., Measuring Anaerobic Sludge Digestion and Growth by a Simple Alkalimetric Titration. Water Pollution Control Federation, 55, 448 (1983).

Latif, M. A., Ghufran, R., Wahid, Z. A., and Ahmad, A., Integrated application of upflow anaerobic sludge blanket reactor for the treatment of wastewaters. Water Research, 45, 4683 (2011).

Liu, Y.-Y., and Haynes, R. J., Origin, nature, and treatment of effluents from dairy and meat processing factories and the effects of their irrigation on the quality of agricultural soils.
Critical Reviews in Environmental Science and Technology, 41, 1531 (2011).

Manyi-Loh, C. E., Mamphweli, S. N., Meyer, E. L., Okoh, A. I., Makaka, G., and Simon, M., Microbial anaerobic digestion (bio-digesters) as an approach to the decontamination of animal wastes in pollution control and the generation of renewable energy. International Journal of Environmental Research and Public Health, 10, 4390 (2013).

Lima, E.V., Tavares, J. C. S., Azevedo, V. R., and Leitão-Lima P. S., Mixture of Brachiaria brizantha seeds with NPK fertilizer. Ciência Rural, 40, 471 (2010).

McCarty, P.L., Anaerobic waste treatment fundamentals. Public Works,95, 107 (1964).

Möller, K., and Müller, T., Effects of anaerobic digestion on digestate nutrient availability and crop growth: A review. Engineering in Life Sciences, 12, 242 (2012).

Moset, V., Poulsen, M., Wahid, R., Hojberg, O., and Moller, H. B., Mesophilic versus thermophilic anaerobic digestion of cattle manure: methane productivity and microbial ecology. Microbial Biotechnology, 8, 787 (2015).

Nikolaeva, S., Sánchez, E., and Borja, R., Dairy wastewater treatment by anaerobic fixed bed reactors from laboratory to pilot-scale plant: A case study in Costa Rica operating at ambient temperature. International Journal of Environmental Research, 7, 759 (2013).

Ogejo, J. A., and Li, L., Enhancing biomethane production from flush dairy manure with turkey processing wastewater. Applied Energy, 87, 3171 (2010).

Page, L. H., Ni, J.-Q., Zhang, H., Heber, A. J., Mosier, N. S., Liu, X., Joo, H.-S., Ndegwa, P.M., and Harrison, J. H., Reduction of volatile fatty acids and odor offensiveness by anaerobic digestion and solid separation of dairy manure during manure storage. Journal of Environmental Management, 152, 91 (2015).

Pohland, F. G., and Ghosh, S., Developments in anaerobic stabilization of organic wastes - The two-phase concept, Environmental Letters, 1(4), 255-266 (1971).

Powar, M. M., Kore, V. S., Kore, S. V, and Kulkarni, G. S., Review on applications of uasb technology for wastewater treatment. International Journal of Advanced Science and Technology, 2, 125 (2013).

Prieto, A. L., Futselaar, H., Lens, P. N. L., Bair, R., and Yeh, D. H., Development and start up of a gas-lift anaerobic membrane bioreactor (Gl-AnMBR) for conversion of sewage to energy, water and nutrients. Journal of Membrane Science, 441, 158 (2013).

Puget, F. P., Melo, M. V., and Massarani, G., Modelling of the dispersed air flotation process applied to dairy wastewater treatment. Brazilian Journal of Chemical Engineering, 21, 229 (2004)

Rico, C., García, H., and Rico, J. L., Physical - anaerobic chemical process for treatment of dairy cattle manure. Bioresource Technology, 102, 2143 (2011a).

Rico, C., Luis, J., Tejero, I., Muñoz, N., and Gómez, B., Anaerobic digestion of the liquid fraction of dairy manure in pilot plant for biogas production : Residual methane yield of digestate. Waste Management, 31, 2167 (2011b). 
Sakar, S., Yetilmezsoy, K., and Kocak, E., Anaerobic digestion technology in poultry and livestock waste treatment - a literature review. Waste Management \& Research, 27, 3 (2009).

Sheets, J. P., Yang, L., Ge, X., Wang, Z., and Li, Y., Beyond land application: Emerging technologies for the treatment and reuse of anaerobically digested agricultural and food waste. Waste Management, 44, 94 (2015).

Silva, E., and Roston, D. M., Treatment of milking parlor effluent: Stabilization ponds followed by constructed wetland. Engenharia Agrícola, 30, 67 (2010).

Spears, J. W., and Weiss, W. P., Role of antioxidants and trace elements in health and immunity of transition dairy cows. The Veterinary Journal, 176, 70 (2008).

Tabatabaei, M., Rahim, R. A., Abdullah, N., Wright, A. D. G.,
Shirai, Y., Sakai, K., Sulaiman, A., and Hassan, M. A., Importance of the methanogenic archaea populations in anaerobic wastewater treatments. Process Biochemistry, 45, 1214 (2010).

Witarsa, F., and Lansing, S., Quantifying methane production from psychrophilic anaerobic digestion of separated and unseparated dairy manure. Ecological Engineering, 78, 95 (2015).

Yao, Y., Zhao, G., Yan, Y., Um, H., Jin, Q., Zou, X., and Wang, X., Milk fat globules by confocal Raman microscopy: Differences in human, bovine and caprine milk. Food Research International, 80, 61 (2016).

Zoetemeyer, R. J., Van Den Heuvel, J. C., and Cohen, A., pH influence on acidogenic dissimilation of glucose in an anaerobic digestor.Water Research, 16, 303 (1982). 